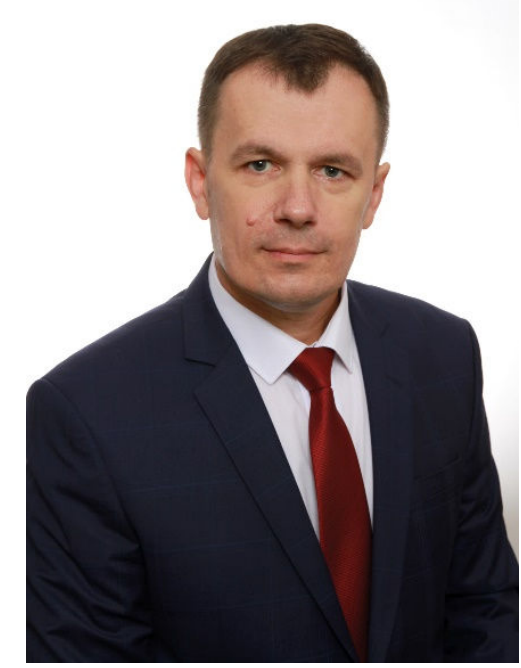

Козар Юрій Юрійович, доктор юридичних наук, професор (Мелітопольський державний педагогічний університет імені Богдана Хмельнииького, м. Мелітополь) ORCID: https://orcid.org/0000-0002-6424-6419

\section{ЕТИКА ДЕРЖАВНОГО СЛУЖБОВЦЯ ЯК ЗАСІБ ЗАПОБІГАННЯ ТА ПРОТИДІЇ КОРУПЦІї}

У статті проаналізовано поняття корупиії, яке міститься в нормах законодавства Украӥни, акцентовано на недоцільності розгляду иьього поняття у вузькому значенні, тобто у виключно кримінально-правовому, та запропоновано способи його вдосконалення. Зазначено, щчо щі способи повинні грунтуватися на міжнародному досвіді. Розглянуто форми протиправних діянь, які включаються до поняття «корупиія», та запропоновано розширити цей перелік шляхом включення до нього таких форм, як «прохання надати», «заволодіння», «нецільове використання» або «набуття». Указано, на яких етапах повинен здійснюватися контроль за дотриманням етичних вимог поведінки у сфері державного управління Украӥни. Обтрунтовано зв'язок між рівнем етики державних службовців та рівнем корупиії.

Ключові слова: корупція; етична поведінка; державний службовеиь; протидія корупиії; міжнародне співробітництво; кодекс етики.

Постановка проблеми. Нині у світі є чимало глобальних проблем. Від вирішення більшості 3 них залежить як подальший розвиток суспільства в цілому, так і кожної людини як індивіда. Однією з найбільш вагомих серед глобальних проблем є проблема корупції, що займає чи не головну позицію, оскільки існує практично в кожній сфері суспільного життя. Також корупція є одним з основних дестабілізаційних факторів будьякого політичного режиму, адже вона руйнує основи державного устрою та створює перешкоди для реалізації прав і свобод людини й громадянина. Корупція заважає розвитку управлінської, політичної та правової систем. Тим самим корупція перешкоджає наближенню України до правової системи Свропейського Союзу (далі - СС).

Зважаючи на те, що корупція в Україні існує на всіх щаблях влади, чимало реформ, необхідних нашій державі, гальмуються. Це стосується навіть тих реформ, які вважаються невідкладними та широкомасштабними. Така всеосяжна корупція в Україні стала можлива у зв'язку 3 низкою факторів, серед яких: лояльне ставлення більшості громадян до корупційних проявів, недотримання етики державними службовцями.

Перегляд питання професійних та етичних стандартів державної служби особливо актуальний з огляду на процес інтеграції європейських цінностей до системи державної служби України.

Аналіз останніх досліджень і публікацій. Проблемам вироблення шляхів подолання корупції, а також підвищення етики державних службовців було присвячено роботи багатьох науковців. Варто виділити фундаментальні дослідження таких іноземних учених, як С. Алатас, Ш. Вей, Ж. Картьє-Брессон, Х. Мілкевич, Г. Мюрдаль, Ф. Фукуяма та ін.

Окремі аспекти корупційної проблематики в Україні розглядають у своїх працях
О. О. Акімов,
П. П. Баранов,
М. М. Білинська,
О. Д. Береза,
А. С. Гальчинський,
С. Д. Дубенко,
С. А. Задорожний,
C. О. Кохан,
Е. С. Молдован,
М. І. Мельник,

(C) Козар Ю. Ю., 2021 

Є. В. Невмержицький,
Н. Р. Нижник,
В. М. Олуйко,
С. М. Серьогін,
M. I. Флейчук, I. О. Христич та ін.

Проте єдиного погляду на те, яким повинен бути механізм боротьби з корупцією, так і немає. Зважаючи на це, у сучасному суспільстві виникла гостра потреба переглянути та оновити науково-методичне забезпечення зазначеної проблематики, у тому числі в питаннях антикорупційної політики держави та іiї морально-етичної складової.

Метою статті є дослідження етики державного службовця як засобу запобігання та протидії корупції.

Виклад основного матеріалу. Сьогодні можна говорити про те, що в Україні існує законодавство, спрямоване на вирішення проблеми корупції. Так, визначення поняття «корупція» міститься в Законі України «Про запобігання корупції» № 1700-VII від 14.10.2014 р. Відповідно до цього Закону корупцією є дії особи щодо використання наданих їй службових повноважень, передбачених законодавством, чи пов'язаних з ними можливостей 3 метою отримання неправомірної вигоди чи прийняття такої вигоди або прийняття обіцянки / пропозиції такої вигоди для себе чи інших осіб або відповідно обіцянка / пропозиція чи надання неправомірної вигоди особі, яка пропонує неправомірну вигоду, або на її вимогу іншим фізичним чи юридичним особам з метою схилити цю особу до протиправного використання наданих їй службових повноважень чи пов'язаних 3 ними можливостей [1].

Унаслідок такого тлумачення поняття «корупція» набуло досить вузького значення, виключно кримінально-правового. Проте безпосередньо корупція становить не тільки корупційний злочин, вчинення якого призводить до настання кримінальної відповідальності, це також порушення норм адміністративного та цивільного законодавства чи дисциплінарних правил.

До того ж у наведеному вище визначенні поняття «корупція» увагу зосереджено на єдиному предметі - неправомірній вигоді, не згадано про наявність інших предметів правопорушень (злочинів), пов'язаних із корупцією. У чинному Кримінальному кодексі України (далі - КК України) містяться інші предмети корупційних правопорушень, до них зокрема відноситься: чуже майно, бюджетні кошти, вогнепальна зброя (крім гладкоствольної мисливської), наркотичні засоби, психотропні речовини, їх аналоги, прекурсори [2].

У визначенні терміна «корупція», наведеному в Законі України «Про запобігання корупції», зазначено не всі форми протиправних діянь. Наприклад, дефініція не містить таких форм, як «прохання надати», «заволодіння», «нецільове використання» або «набуття».

На міжнародному рівні питання корупції регулюють багато актів, серед яких: Цивільна конвенція про боротьбу з корупцією від 04.11.1999 року [3], Кримінальна конвенція про боротьбу з корупцією від 27.01.1999 року [4], Конвенція ООН проти корупції від 31.10.2003 року [5], Додатковий протокол до Кримінальної конвенції про боротьбу з корупцією [6].

У нормах Цивільної конвенції про боротьбу з корупцією від 04.11.1999 року міститься визначення корупції, проте варто зауважити, що воно є досить абстрактним. Так, відповідно до цієї Конвенції корупцію розуміють як «прямі чи опосередковані вимагання, пропонування, дачу або одержання хабара чи будь-якої іншої неправомірної вигоди або можливості іiї отримання. Такі дії порушують належне виконання службового обов'язку особою, що отримує хабара, неправомірну вигоду чи можливість мати таку вигоду, або поведінку такої особи» [3].

Дослідивши міжнародний досвід щодо змістовного наповнення поняття «корупція», можна зробити висновок, що законодавством України це поняття розглядається досить вузько. Для вдосконалення поняття «корупція» необхідно доповнити його визначення низкою категорій, про які попередньо зазначалося. Ці категорії дадуть можливість 
розширити та уточнити межі предмета корупції, а також діянь, які входять до їі складу, та наслідків.

Те, що етичний рівень державного службовця має безпосередній вплив на прояви корупції у його діяльності, є очевидним, цю думку поділяє багато вчених. Такий зв'язок простежується також у нормах законодавства. Так, у Законі України «Про запобігання корупції» від 14.10.2014 року правилам етичної поведінки службовців присвячено окремий розділ. Показовим $\epsilon$ те, що згідно з дослідженнями науковців серед корупційних ризиків перше місце займає низький рівень етики державних службовців.

Дотримання чи порушення етичних норм має досить вагомий вплив на чесність державних службовців у період виконання ними своїх обов'язків. Зумовлено це тим, що державний службовець, приймаючи рішення, спирається насамперед на власний досвід, психологічне ставлення до виконуваної роботи, а також на особисті переконання.

Підтримка високого рівня етичності державного службовця може здійснюватися декількома шляхами:

1) через самостійну регуляцію моральності державних службовців;

2) через інституційний вплив, який максимально унеможливлює порушення етичних вимог професії державного службовця.

Необхідно здійснювати контроль за дотриманням етичних вимог у державному управлінні. Такий контроль може бути на етапах:

1) відбору осіб на державну службу;

2) проходження професійної діяльності - оцінюючи дотримання норм етики державного службовця [7].

Очевидним є те, що для зменшення рівня корупції в Україні потрібно на якісно новий рівень вивести етику державних службовців.

Резолюція Генеральної Асамблеї ООН 3514 (ХХX), ухвалена 15 грудня 1975 року, є одним із перших міжнародних документів, у якому розглянуто всі види корупції, зокрема хабарництво. Ця резолюція закликає всі країни до запровадження на національному рівні низки необхідних заходів, які будуть сприяти боротьбі з корупцією. Перелік таких заходів резолюцією не закріплено. Те, які саме заходи будуть застосовуватися, повинно бути визначено на розсуд урядів країн.

Нині на міжнародному рівні прийнято досить велику кількість актів, які стосуються питання боротьби з корупцією, робота в цій сфері продовжується. Цей процес не оминув і нашої держави. Україною підписано низку важливих міжнародних антикорупційних угод. Серед них можна виокремити:

1) Конвенцію ООН проти корупції;

2) Цивільну конвенцію про боротьбу з корупцією;

3) Кримінальну конвенцію про боротьбу з корупцією;

4) Додатковий протокол до Кримінальної конвенції про боротьбу з корупцією.

Наша держава $є$ членом ГРЕКО (Групи країн проти корупції) 31 січня 2006 року. Із цього часу Україна стала сороковим членом цієї організації. Стати членом ГРЕКО наша держава змогла завдяки набуттю для України чинності Цивільної конвенції Ради Європи про боротьбу з корупцією [8].

Однією 3 основних форм співробітництва держав у боротьбі 3 корупцією $\epsilon$ Організація економічного та соціального розвитку (далі - ОЕСР). Зокрема, Антикорупційна мережа цієї організації для Східної Європи та Центральної Азії має вагомий вплив на розробку міжнародних документів щодо боротьби з корупцією.

У рамках роботи ОЕСР у 2003 році було розроблено та схвалено Стамбульський план дій з боротьби проти корупції Антикорупційної мережі для Східної Європи та Центральної Азії ОЕСР.

До основних принципів цього плану належать:

1) розвиток ефективної і прозорої системи державної служби; 
2) посилення протидії хабарництву;

3) стимулювання ведення бізнесу відкрито;

4) стимулювання громадян брати активну участь у здійсненні реформ [9].

Відповідно до положень статті 8 Конвенції Організації Об'єднаних Націй проти корупції, країни-учасниці повинні розробити кодекси поведінки державних посадових осіб, а також запровадити заходи й системи, які:

- сприяють зверненням державних службовців до належних органів із повідомленнями про корупційні діяння, про які їм стало відомо під час виконання ними своїх обов'язків;

- зобов'язують державних посадових осіб подавати декларації до відповідних органів;

- у установлюють відповідальність державних посадових осіб за порушення норм кодексів етичної поведінки.

23 квітня 1998 року Організація економічного співробітництва і розвитку прийняла Рекомендацію з покращення етики поведінки на державній службі, відповідно до якої етичні норми, якими повинні керуватися державні службовці, мають бути чітко викладеними та зрозумілими.

Згідно 3 Рекомендацією європейським країнам «Про кодекси поведінки для державних службовців» Комітет міністрів пропонував урядам усіх країн якнайповніше сприяти прийняттю кодексів поведінки службовців на національних рівнях. Крім того, уряди повинні керуватися Модельним кодексом поведінки державних службовців. 3 аналізу цієї рекомендації зрозуміло, що Комітет міністрів Ради Європи впевнений, що підвищення рівня етичних цінностей службовців $\epsilon$ важливим засобом у попередженні корупції. Норми Модельного кодексу встановлюють вимоги до поведінки службовців під час виконання ними своїх обов'язків.

Комітет міністрів Ради Європи зобов'язав стежити за виконанням цієї рекомендації Групу країн проти корупції (ГРЕКО). Тому вказаною групою за результатами оцінювання Україні було рекомендовано створити новий Модельний кодекс поведінки / етики для службовців публічної сфери. Метою цього кодексу повинна бути реалізація програм навчання державних службовців щодо виконання ними відповідних зобов'язань, пов'язаних із дотриманням певної поведінки відповідно до їх служби.

Свропейський омбудсмен на основі Правил державних службовців та умов працевлаштування інших службовців Європейського Економічного Співтовариства та Європейського об'єднання з атомної енергії (1961р.) виокремлює принципи державної служби, які застосовуються до всіх працівників установ ЄС, та декларує такі основні принципи, як служіння ЄС і його громадянам, доброчесності, об'єктивності й прозорості [10].

Хоч Україна є членом провідних міжнародних організацій, метою діяльності яких $\epsilon$ запобігання та протидія корупції, проте нашій державі ще потрібно здійснити низку комплексних перетворень у законодавстві, щоб воно відповідало міжнародним нормам та було ефективним.

Згідно з дослідженнями найменш корумпованими країнами світу є Данія, Нова Зеландія та Фінляндія (незначний рівень корупції також у Швеції, Швейцарії, Норвегії, Сінгапурі, Канаді та Німеччині) [11]. Хоча механізми цих країн мають певні відмінності, проте всі вони функціонують виключно зі спільною метою: активна боротьба з корупцією.

У Фінляндії антикорупційна діяльність базується на особливій системі правосвідомості громадян. Саме високий рівень правосвідомості не дозволяє давати й брати хабарі. У зв'язку з цим у країні немає необхідності створювати ні спеціального антикорупційного законодавства, ні спеціального органу для протидії з корупцією.

У Швеції механізм запобігання та протидії корупції грунтується на таких чотирьох основних принципах:

1) заборона особистих контактів чиновника та громадянина; 
2) обов'язкове декларування доходів;

3) обмеження готівкових розрахунків;

4) повна відкритість діяльності влади.

Усі декларації державних службовців - у відкритому доступі. До повноважень фіскальних органів належить регулярна перевірка декларацій на виявлення ознак раптового збагачення.

У Новій Зеландії функціонують антикорупційні органи, головним серед яких є SFO - спеціальне відомство 3 боротьби проти шахрайства у великих розмірах. Цей орган наділений значними повноваженнями щодо протидії корупції. Зокрема, SFO має право проводити аналіз декларацій громадян.

У Данії працює «гаряча лінія» при Агентстві міжнародного розвитку. Створена вона для того, щоб забезпечити можливість повідомити про будь-яку особу, підозрювану в неправомірних діях, пов'язаних із корупцією.

США має багатий досвід із запровадження етичної програми в системі виконавчої влади. У США розроблено та введено в дію розгалужену систему спеціального «етичного» законодавства. Відповідно до цього законодавства й на його основі утворена й успішно функціонує окрема «етична» державна структура управління. До завдань указаної структури належать: регулювання, розслідування, переслідування неетичних дій державних службовців. Також у США запроваджено спеціальні процедури вирішення «етичних» справ і механізми примусового застосування етичних норм до державних службовців, які порушили встановлені норми. Законом 1978 р., який передбачав реформування державного врядування, визначено заходи, спрямовані на зменшення рівня корупції, а також на збільшення рівня ефективності діяльності державних установ. Відповідно до законодавства США державний службовець не може приймати цінності за здійснення дій, тобто отримувати хабарі. Службовцям заборонено також брати офіційну участь у справі, що має для нього або може мати в майбутньому інтерес, вести справу, яка не містить корупції, але може спричинити іiі. У 1989 р. Конгресом США було засновано окрему установу в системі виконавчої влади під назвою Управління державної етики.

В Україні корупційні дії пов'язують із використанням тільки державної влади в корисних цілях, що призводить до обмеження корупції колом посадових осіб державного сектору. Але скандали, які вибухнули останнім часом, пов'язані з бухгалтерськими шахрайствами на приватних підприємствах у США та інших країнах, доводять, що корупція може існувати також у приватному секторі.

Як свідчить досвід перерахованих вище країн, низький рівень корупції обумовлено, зокрема, високим рівнем етики державних службовців.

Висновки. 3 метою подолання корупції етичні норми поведінки осіб, які займають посади державної служби, повинно бути відображено в правовій системі. Зумовлюється така необхідність тим, що саме закони та інші нормативні акти є основою подолання корупції. У зв'язку з цим законодавчі акти України потребують удосконалення, особливо щодо питання дефініції поняття «корупція».

За роки незалежності України у сфері подолання корупції було зроблено досить багато: прийнято спеціальний антикорупційний закон та низку інших законодавчих актів антикорупційного спрямування, ратифіковано міжнародні акти з боротьби проти корупції. Також Україна $є$ членом міжнародних організацій, діяльність яких спрямована на подолання корупції.

Проте корупція в Україні продовжує процвітати. Вагомий вплив на це здійснює етика службовців, оскільки високий рівень етики осіб, які перебувають на державній службі, має чималу антикорупційну спрямованість. Для того щоб громадяни були впевнені в чесності державних службовців, кожен із останніх повинен неухильно дотримуватися принципів етичної поведінки під час виконання своїх обов'язків. 
Правовий часопис Аонбасу № 4 (77) 2021

Зважаючи на досвід країн із низьким рівнем корупції, українським державним службовцям варто запозичити такі механізми боротьби з корупцією:

1) підвищення правосвідомості громадян;

2) забезпечення відкритої діяльності осіб, які перебувають на державній службі;

3) ефективне функціонування контрольних органів влади;

4) у удосконалення механізму декларування доходів державних службовців.

\section{Список використаних джерел}

1. Про запобігання корупції: Закон України від 14.10.2014 № 1700-VII. URL: http://zakon3.rada.gov.ua/laws/show/1700-18 (дата звернення: 19.03.2021).

2. Кримінальний кодекс України від 05.04.2001 № 2341-ІІІ. Відомості Верховної Ради України. 2001. № 25. Ст. 131.

3. Цивільна конвенція про боротьбу з корупцією (ETS 174) : прийн. 4 листоп. 1999 р. у Страсбурзі; ратиф. Україною 16 берез. 2005 p. URL: http://zakon.rada.gov.ua/laws/show/994_102 (дата звернення: 19.03.2021).

4. Кримінальна конвенція про боротьбу з корупцією від 27.01.1999 року; ратифікована Україною 18.10.2006. URL: https://zakon.rada.gov.ua/laws/show/994_101\#Text (дата звернення: 19.03.2021).

5. Конвенція ООН проти корупції від 31.10.2003 року; ратифікована Україною 18.10.2006. URL: https://zakon.rada.gov.ua/laws/show/995 c16\#Text (дата звернення: 19.03.2021).

6. Додатковий протокол до Кримінальної конвенції про боротьбу з корупцією; ратифіков. Україною 18.10.2006. URL: https://zakon.rada.gov.ua/laws/show/994_172\#Text (дата звернення: 19.03.2021).

7. Роз'яснення Міністерства юстиції України «Корупційні ризики в діяльності державних службовців» від 12.04.2011 року. https://zakon.rada.gov.ua/laws/show/n0026323-11\#Text (дата звернення: 20.03.2021).

8. Участь України в міжнародному співробітництві у сфері запобігання та протидії корупції : лист Міністерства юстиції України. URL: https://zakon.rada.gov.ua/laws/show/n0042323-11\#Tехt (дата звернення: 18.03.2021).

9. Стамбульський план дій 3 боротьби проти корупції. URL: https://zakon.rada.gov.ua/laws/show/966_001-04\#Техt (дата звернення: 19.03.2021).

10. Regulation No 31 (EEC), 11 (EAEC), laying down the Staff Regulations of Officials and the Conditions of Employment of Other Servants of the European Economic Community and the European Atomic Energy Community, 1961. URL: https://eur-lex.europa.eu/legalcontent/EN/TXT/?uri=CELEX\%3A01962R0031-20140501 (дата звернення: 19.03.2021).

11. Індекс корупції CPI-2016. URL: https://ti-ukraine. org/research/indeks-koruptsiyi-cpi-2016/ (дата звернення: 20.03.2021).

\section{References}

1. Pro zapobihannia koruptsii : Zakon Ukrainy [On Preventing Corruption : Law of Ukraine] vid 14.10.2014 № 1700-VII. URL: http://zakon3.rada.gov.ua/laws/show /1700-18 (data zvernennia: 19.03.2021). [in Ukrainian].

2. Kryminalnyi kodeks Ukrainy [Criminal Code of Ukraine] vid 05.04.2001 № 2341-III. Vidomosti Verkhovnoi Rady Ukrainy. 2001. № 25. St. 131 [in Ukrainian].

3. Tsyvilna konventsiia pro borotbu z koruptsiieiu (ETS 174) [Civil Law Convention on Corruption (ETS 174)] : pryin. 4 lystop. $1999 \mathrm{r}$. u Strasburzi; ratyf. Ukrainoiu 16 berez. 2005 r. URL: http://zakon.rada.gov.ua/laws/show/994_102 (data zvernennia: 19.03.2021) [in Ukrainian].

4. Kryminalna konventsiia pro borotbu z koruptsiieiu [Criminal Law Conventionon Corruption] vid 27.01.1999 roku; ratyfikovana Ukrainoiu 18.10.2006 URL: https://zakon.rada.gov.ua/laws/show/994_101\#Text (data zvernennia: 19.03.2021) [in Ukrainian].

5. Konventsiia OON proty koruptsii [The United Nations Convention against Corruption] vid 31.10.2003 roku; ratyfikovana Ukrainoiu $18.10 .2006 . \quad$ URL: https://zakon.rada.gov.ua/laws/show/995_c16\#Text (data zvernennia: 19. 03.2021) [in Ukrainian].

6. Dodatkovyi protokol do Kryminalnoi konventsii pro borotbu z koruptsiieiu [Additional Protocol to the Criminal Law Convention on Corruption]: ratyfikovana Ukrainoiu 18.10.2006. URL: https://zakon.rada.gov.ua/laws/show/994_172\#Text (data zvernennia: 19.03.2021) [in Ukrainian].

7. Roziasnennia Ministerstva yustytsii Ukrainy «Koruptsiini ryzyky v diialnosti derzhavnykh sluzhbovtsiv» [Explanation of the Ministry of Justice of Ukraine "Corruption Risks in the Activities of Public 
Officers"] vid 12.04.2011 roku. URL: https://zakon.rada.gov.ua/laws/show/n0026323-11\#Text (data zvernennia: 20.03.2021) [in Ukrainian].

8. Uchast Ukrainy v mizhnarodnomu spivrobitnytstvi u sferi zapobihannia ta protydii koruptsii : Lyst Ministerstva yustytsii Ukrainy [Participation of Ukraine in International Cooperation against Corruption : Letter of the Ministry of Justice of Ukraine]. URL: https://zakon.rada.gov.ua/laws/show/n0042323-11\#Text (data zvernennia: 18.03.2021) [in Ukrainian].

9. Stambulskyi plan dii $\mathrm{z}$ borotby proty koruptsii[Istanbul Anti-Corruption Action Plan]. URL: https://zakon.rada.gov.ua/laws/show/966_001-04\#Text (data zvernennia: 19.03.2021) [in Ukrainian].

10. Regulation No 31 (EEC), $1 \overline{1}$ (EAEC), laying down the Staff Regulations of Officials and the Conditions of Employment of Other Servants of the European Economic Community and the European Atomic Energy Community, 1961. URL: https://eur-lex.europa.eu/legalcontent/EN/TXT/?uri=CELEX\%3A01962R0031-20140501 (data zvernennia: 19.03.2021).

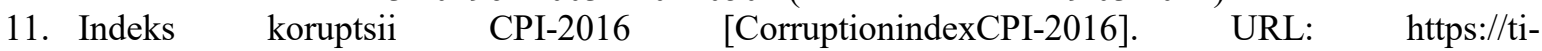
ukraine.org/research/indeks-koruptsiyi-cpi-2016/ (data zvernennia: 20.03.2021) [in Ukrainian].

\author{
Kozar Yurii, \\ Doctor of Law, Professor \\ (Bogdan Khmelnytsky Melitopol State Pedagogical University, Melitopol) \\ ORCID: https://orcid.org/0000-0002-6424-6419
}

\title{
ETHICS OF PUBLIC OFFICER AS A MEANS OF ANTI-CORRUPTION
}

The article analyzes the concept of corruption, which is contained in the legislation of Ukraine, substantiates the inexpediency of considering this concept in the narrow sense, that is in the exclusively criminal law, and suggests ways to improve it. It is noted that the proposed methods should be based on international experience. It is analyzed what forms of illegal acts are included in the concept of corruption and it is proposed to expand this list by including such forms as "request to provide", "possession", "misuse" or "acquisition". It is indicated at what stages the control over observance of ethical requirements of behavior in the sphere of public administration of Ukraine should be carried out. The connection between the level of ethics of public officer and the level of corruption is substantiated. The article also analyzes the international law on corruption and the ethics of public officers. In particular, attention is paid to the Recommendations of the Council of Europe. It is noted which international anticorruption instruments have been ratified by Ukraine. The article also deals with the activities of Ukraine in the Organization for Economic and Social Development. Attention is paid to the experience of other countries in anti-corruption, special attention is paid to the regulation of public officers' ethics in these countries. The experience in anti-corruption in the least corrupt countries of the world, Denmark, New Zealand, and Finland, is described. The process of introducing programs to improve the level of ethics in the system of executive power in the United States is analyzed. The US legislation in this area is described. It is emphasized that in this country there are special procedures for resolving cases of ethical violations in the civil service and mechanisms for enforcement of rules governing ethical conduct, in particular through the activities of authorized bodies. The need to expand the scope of corruption to non-state institutions is substantiated.

Key words: corruption; ethical behavior; public officer; anti-corruption; international cooperation; codeofethics.

Надіслано до редколегії 15.11.2021 Рекомендовано до публікації 19.11.2021 